nical education and promote attention to scientific method in all national affairs.

Another fruit of the war is the awakened interest in the subject of education on the part of large employers, and especially of the importance of scientific training and research. A Committee of the Privy Council has been instituted for the purpose of encouraging scientific and industrial research, with numerous sub-committees dealing with various sections of industry and with special products. Ten research associations have been formed in respect of the chief industries, and twenty-eight important researches have been undertaken and aided from the fund of $\mathrm{r} ; 000,000 l$. placed at the disposal of the Committee by Parliament.

The Education Act of 1918, which should be made operative without delay, will, when it comes into full effect, supply a far higher type of student for our arts and industries. As showing the advance within the last fifty years, there were at the beginning of that period only four universities which granted degrees in England and Wales, one of which (London) was merely an examining body. Now there are eleven duly incorporated, with numerous colleges attached to them, many of them chiefly concerned with technical training and education. These universities are all well equipped and staffed for the teaching of science and its applications, in the encouragement of which this journal has borne no small share since its foundation in 1869 .

Yet we have still far to go if we would keep ourselves abreast of foreign educational enterprise. There were in 1914 twenty-one universities in Germany, with 68,000 students, against eighteen in the United Kingdom, with 27,000 students. There were also eleven technical high schools in Germany, and sixteen other special high schools for agriculture, mining, etc., with $2 \mathrm{r}$, ooo students, as against 5000 in ours, and in both age and standard of education at entrance their students rank much higher than ours. The State grants to universities and colleges in the United Kingdom were about 500,00ol., in Germany nearly 2,00o,oool, and in the United States $7,000,000 l$., but in addition there was given nearly $4,000,000 l$. in private benefactions, as compared with 200,00ol. in the United Kingdom. To maintain our position as a leading nation in industry and commerce, we need to increase the potentiality of our manhood, to secure which will require a much larger expenditure of money and effort. We want accomplished leaders and a welleducated and highly trained rank and file.

\title{
THE PROMOTION OF RESEARCH.
}

\section{By Sir Richard A. Gregory.}

The great inventions of former ages were made in countries where practical life, industry, and commerce were most advanced; but the great inventions of the last fifty years in chemistry and electricity and the science of heat have been made in the scientific labora. tory: the former were stimulated by practical wants, the latter themselves produced new practical require. ments, and created neiv spheres of labour, industry, and commerce.-J. T. MrRz.

THE recognition of the value of scientific research as a determining factor of progressive development has been a common note of many public utterances in recent years. Ministers and labour leaders, manufacturers and men of letters, are impressed with the results of experimental inquiry and do homage to those who devote their lives to it. Rarely, however, is the spirit which prompts most scientific investigations understood. "The quickening power of science, only he can know from whose soul it gushes frec." It seeks not to use, but to know : its aim is not an engine of war or a profitable invention, but the discovery of new knowledge and the creation of new ideas for all mankind. Researches which have practical applications as their proximate or ultimate ends are not likely in these days to need much advocacy for their support, but those which have no such aims must, like virtue, carry their own reward with them. The standard of value to-day, more than ever it was, is worldly riches, and if all research had to be measured by it science might gain the whole world, but it would lose its own soul by so doing.

$$
\text { NO. } 26 \text { IO, VOI. IO4] }
$$

When the State or the manufacturer makes provision for research, tangible results are expected, and freedom to explore what, from a practical point of view, seem to be unpromising bypaths is discouraged. To a certain extent $\mathrm{Mr}$. Gladstone was right when in 1872 he termed the intervention of the State as "interference" with science, calculated to discourage individual exertion and so obstruct discovery and progress. The view then taken was that the more science was left to itself the better for it. We are far from accepting this laissez faire principle entirely, but there is some truth in it so far as purely scientific research is concerned. Creative genius never has been, and never will be, willing to submit to bureaucratic control or industrial needs, yet it discovers the new lands in which rich fruits are afterwards cultivated for the benefit of the world. While, therefore, we acknowledge with much satisfaction the growing appreciation of research as a means of promoting industrial advance, we trust that the apparently useless and unpractical pursuits of purcly scientific workers will be regarded as equally worthy of encouragement.

When the publication of NATURE was begun fifty years ago, experimental research received little or no support from the State. Astronomical work was carried on at the Royal Observatory, Greenwich, and natural history objects were displayed at the British Museum, but there was absolutely no provision in this country for the support of experimental investigation of a modern 
type. It was pointed out in these columns in 1872 that great laboratories had been erected in Berlin, Leipzig, Bonn, Aix-la-Chapelle, Karlsruhe, Stuttgart, Griefswald, and other places, at the expense of the State, and special provision had been made in them for original scientific research, but no like developments had taken place here. When a deputation of the Council of the British Association waited upon Earl Grey, Lord President of the Council, in 1870 , to urge on the Grovernment the issuing of a Royal Commission to inquire into the state of science in England, Lord Grey thought that the whole inquiry was fraught with difficulties, but the object was worthy of a statesman's ambition. The Commission was appointed in the same year, with the seventh I)uke of Devonshire as president and Sir Norman I.ockyer as secretary; and the volumes of its reports issued from 187 r to 1875 are filled with convincing evidence and far-seeing suggestions.

The terms of reference of the Commission were "to make inquiry with regard to scientific instruction and the advancement of science, and to inquire what aid thereto is derived from grants voted by Parliament, or from endowments belonging to the several universities in Great Britain and Ireland, and the colleges thereof, and whether such aid could be rendered in a manner more effectual for the purpose." The whole position of science in the Lnited Kingdom was surveyed in the volumes of the report of the Commission; and had the recommendations of the Commissioners been acted upon, we should easily have been in advance of all other countries in the applications of science to industry, and have been strongly equipped for all eventualities of peace or of war. Our statesmen had not sufficient knowledge of science to understand its relation to national advancement, or sufficient faith in scientific discovery to believe that provision for it would ultimately benefit the community industrially and politically; and we lost ground in consequence of their neglect.

One of the recommendations of the Commission was that a special department of science should be entrusted with the duty of promoting the scientific interests of the country. It was proposed that a Ministry of Science should be constituted, with a permanent and well-paid scientific council to advise the Government on scientific questions, consider inventions tendered for the use of the State, and conduct or superintend experimental investigations relating to such matters. The Department of Research and Information outlined in the Report on the Machinery of Government issued by the Ministry of Reconstruction a few months ago is intended to scrve much the same purposes as were contemplated by the Duke of Devonshire's Commission. It is permissible in this connection to recall a communication to NAture of June 15,1871 , in which I.t.-Col. A. Strange described the work which a Ministry of Science could undertake, and added, in words NO. 26 IO, VOL. IO4] which are as apt to-day as they were when they were written :

When we have all scientific national institutions under one Minister of State, advised by a permanent, independent, and highly-qualified consultative bodywhen we have a similar body to advise the Ministers of War and Marine in strategical science-then the fact that, in accordance with our marvellous constitu. tion, these ministers must almost necessarily be men without pretension to a knowledge of the affairs which they administer, need cause us no alarm. When these combinations have been, as they assuredly will be, sooner or later, effected, the wealth, resources, and intelligence of the nation, having due scope, will render us unapproachable in the arts of peace and unconquerable in war-but not till then.

Though the Ministry of Science advocated fifty years ago has not been realised, the Department of Scientific and Industrial Research established in 1916 fulfils many of its functions and is likely to undertake further work for the co-ordination and development of national scientific activities if the recommendations of the Report on the Machinery of Government are ever carried out. The Department has a fund of one million pounds voted by Parliament as a block grant to be expended over a period of five or six years. This fund is being used to make grants towards the foundation and maintenance of approved associations for research on a co-operative basis. In addition, the Department has at its disposal an annual Parliamentary vote to cover the cost of researches not undertaken by the research associations, to provide grants to research workers, and for administration. The Department also now administers the National Physical Laboratory, which was founded in 1899 , and to which the sum of $155,000 l$. is allocated in the Civil Service Estimates for the current financial year.

National provision for scientific work has thus been considerably extended in recent years. The official attitude of earlier days was represented by a reply which the Lords Commissioners of H.M. Treasury made to an application from the British Association in 1872 for a grant of $150 l$. to secure the continuance of some important tidal observations. The reply was :

I am to state that their I.ordships have given their anxious attention to the memorial, and that they are fully sensible of the interesting nature of such investigations, but that they feel that if they acceded to this request it would be impossible to refuse to contribute towards the numerous other objects which men of eminence may desire to treat scientifically. Their I,ordships must, therefore, though with reciret. decline to make a promise of assistance towards the present object out of public funds.

It will be evident from this example of the position of State support for science in England in 1872 that much remained to be done in order to change the official mind which after "anxious attention" had to express "regret" that the Government of these islands could not provide the sum of $150 l$. for tidal obscrvations because 
further demands might be made for the support of other investigations. It is not too much to say that NATURE has been largely responsible for bringing about a more encouraging attitude towards scientific research on the part both of statesmen and the public generally. Throughout its existence this journal has consistently and persistently advocated increased attention by the State to scientific investigation and the need for liberal endowment of all work by which natural knowledge is increased. It is gratifying to know that the principle of national responsibility for the fostering of these research activities has in recent years been officially accepted.

Fifty years ago the provision made by Parliament for the promotion of science in the United Kingdom was an annual grant of roool., which was administered by the Royal Society. In 1876 a further grant of $4000 l$. was voted for "the payment of personal allowances to gentlemen during the time they are engaged in their investigations." In 1882 the grant of roool. was discontinued, and that of $4000 l$. has been included since then in the Civil Service Estimates without increase. The Royal Society, which administers the grant, derives no pecuniary benefit from it, and it only shares to the extent of a few hundred pounds annually in the additional annual grant of roool. made to assist in defraying the expenses of scientific publication. If this grant were increased to ten times the amount it could be effectively used by scientific societies, for the costs of publication are now very heavy and the output of papers or other works worthy of publication is much greater than when the grant was originally made in 1894 .

In the Estimates for $1869-70$ a grant of roool. to the Royal Society, 5ool. to the Royal Geographical Society, and 300 . to the Royal Society of Edinburgh, together with other grants for scientific investigation, were classified together as votes for learned societies, with a total of $12,300 l$. The total amount for scientific and other institutions in the Estimates for 1919-20 is about I 14, oool., but this includes 47, oool. for the Meteorological Office, and 20,00ol. for the National Museum of Wales. In addition, the grants for investigation and research under the Department of Scientific and Industrial Research are estimated at $93,570 l$., and there is a grant of $12,775 \mathrm{l}$. for the Fuel Research Station.

State grants to Colleges of London and Manchester were recommended by the Devonshire Commission in 1874 , but the first direct assistance of this kind from the National Exchequer was a grant of 4000 . to the University College of Wales in 1883 . In $1889-90$ a vote of $15,000 l$. was included in the Estimates for University Colleges in England, in addition to $12,000 l$. for the three University Colleges of Wales. The total grant under that vote was then $44,785 l$., and now -thirty years later - the total amount of the grants to be paid out of the Exchequer for the maintenance of university institutions in the United NO. 26 IO, VOL. IO4]
Kingdom during the year I9I9-20 is $1,000,000 l$. Though the increase is substantial, there are more institutions to participate in the grant, and much larger staffs and more elaborate equipment are necessary, so that it cannot be said even now that adequate provision has been made by the State for university education.

In university grants and gifts, as in those for research, the tendency is to promote the applied sciences and to overlook the needs of departments concerned particularly with knowledge of no apparent practical value. It is forgotten that the great advances in the industrial sciences of modern times, those which have raised the industrial and commercial life of the community, and so enormously increased its wealth, have had their origin in university laboratories and like places of what may be termed academic study. Investigations and discoveries on the borderlands of science, and leading to no immediately useful results for mankind, are often in the end the most valuable. It is the duty of universities to provide encouragement and training for men and women who possess special capacities for carrying on work of this kind; and a wise State will see that these workers are provided with full facilities for the cultivation of their abilities, as well as freedom to follow what seem to them the most promising paths of investigation. A scientific research laboratory cannot be conducted on the lines of a business house in which each department has to justify its existence by profitable returns. It must be independent of its patron, whether this be represented by a State department or by a governing body of commercial men. Unless this is so, our university laboratories and our research workers in fields of pure science may be reduced to the condition of some of the universities in the United States, amusingly illustrated by President Maclaurin, of the Massachusetts Institute of Technology, as follows:

The superintendent of buildings and grounds, or other competent authority, calls upon Mr. Newton.

Superintendent: Your theory of gravitation is hanging fire unduly. The director insists upon a finished report, filed in his office by 9 a.m. Monday next; summarised on one page; typewritten, and the main points underlined. Also a careful estimate of the cost of research per student-hour.

Nereton: But there is one difficulty which has been puzzling me for fourteen years, and I am not quite ...

Superintendent (with snap and vigour). Guess you had better overcome that difficulty by Monday morning or quit.

The absurdity of the picture is manifest; yet there is a tendency to regard research as more or less routine work in which results can be ordered and measured as they can by methods of scientific efficiency in industry. This is the present danger, and it is the duty of all who cherish increase of knowledge to see that such inhibitory conditions are excluded in our laboratories of creative science. 